Genij Ortopedii. 2021. Vol. 27, no. 5. P. 514-520.

Original article

DOI 10.18019/1028-4427-2021-27-5-514-520

\title{
Hematological parameters of rheumatoid arthritis patients undergoing total hip replacement
}

\author{
A.S. Ershov ${ }^{1,2}$, I.P. Antropova ${ }^{1,3 凶}$, E.A. Volokitina ${ }^{1}$, L.P. Evstigneeva ${ }^{1,2}$
}

${ }^{1}$ Ural State Medical University, Ekaterinburg, Russian Federation

${ }^{2}$ Sverdlovsk Regional Clinical Hospital No. 1, Ekaterinburg, Russian Federation

${ }^{3}$ Institute of High Temperature Electrochemistry of the Ural Branch of the Russian Academy of Science, Ekaterinburg, Russian Federation

Corresponding author: Irina P. Antropova, aip.hemolab@mail.ru

\section{Abstract}

Background Patients with rheumatoid arthritis (RA) and baseline anemia may have an increased risk of complications after total hip replacement (THR). Inflammation in RA is the main factor manifesting anaemia, neutropenia, thrombocytosis and eosinophilia. The changes in blood components are important for the outcomes of major orthopaedic surgery. The purpose was to identify hematological parameters in RA patients undergoing THR and assess the effect on intraoperative blood loss. Material and methods Outcomes of 44 THR patients treated for grade III degenerative coxarthrosis ( $\mathrm{n}=21$, OA group) and RA coxarthrosis ( $\mathrm{n}=23$, RA group) in Ekaterinburg regional hospital № 1 between 2018 and 2019 were reviewed. The patients' age ranged from 41 to 70 years. Clinical, radiological, laboratory examinations, computed tomography and statistical analysis were used for the study. Cell counting was produced with the Sysmex XT-4000i automated hematology system. Statistical analysis was performed using the tools of Statistica software. Non-parametric Mann-Whitney test was used to compare cell counts between the groups. The Spearman Rank correlation was used to analyse the correlation between the the cell counts in the groups. For calculations, a significance level of $\mathrm{p}<0.05$ was adopted. Results There were no significant differences in the preoperative white blood cell (WBC), neutrophil, lymphocyte, monocyte, eosinophil counts between RA and OA groups. The RA group showed an evident decrease in red blood cell (RBC) count and haemoglobin level as compared to OA group. The RA group demonstrated the higher platelet count with mean platelet volume (MPV) being significantly lower than that in the OA group. WBC count, neutrophils, in particular, was shown to increase with lymphocyte, RBC, platelet count and hemoglobin, plateletcrit levels decreased at 24 hours postoperatively. There were no significant differences in WBC and RBC counts in the groups postoperatively. The differences in the MPV were leveled up in the groups with the platelet count being higher in the RA group as compared to the OA group. Conclusions Hematological parameters of RA patients who had undergone specific preoperative preparation were not shown to be associated with greater blood loss during hip replacement surgery. The leukocyte count leveled up in the preoperative and early postoperative periods can be indicative of the absence of a significant effect of RA on the postoperative inflammation.

Keywords: total hip replacement, rheumatoid arthritis, osteoarthritis, platelets, hematological parameters

For citation: Ershov A.S., Antropova I.P., Volokitina E.A., Evstigneeva L.P. Hematological parameters of rheumatoid arthritis patients undergoing total hip replacement. Genij Ortopedii, 2021, vol. 27, no 5, pp. 514-520. https://doi.org/10.18019/1028-4427-2021-27-5-514-520.

\section{INTRODUCTION}

Rheumatoid arthritis (RA) is a systemic autoimmune disease characterized by synovial inflammation, progressive destruction of joints and extra-articular manifestations including blood system changes. RA people with severely impaired joints may elect to have total joint replacement surgery to improve the musculoskeletal function of the affected joint and significantly reduce joint pain [1]. Implantation of an artificial hip or knee joint is a rather traumatic surgical intervention that can be accompanied by deep inflammation and often complicated by significant blood loss and /or thrombosis [2, 3]. Prior research suggests that RA persons undergoing total joint arthroplasty are at increased risk of complications including baseline anemia, low hemoglobin levels that may require a perioperative blood transfusion [4-6]. Clinical results of total arthroplasty of major joints are reported to be worse in RA patients than those of a similar surgery in OA $[5,7,8]$. There is evidence that a risk of complications is not greater in RA patients who have undergone total arthroplasty of a major joint than that for OA patients $[9,10]$. In a highvolume center, with high RA-specific experience, RA does not increase postoperative adverse events compared to OA patients [11]. The inflammation in RA is the main factor manifesting anemia, neutropenia, thrombocytosis and eosinophilia $[12,13]$. It is evident that the blood system changes observed in RA patients are important for the outcomes of major orthopedic interventions.

The purpose was to identify hematological parameters in RA patients undergoing THR and assess the effect on intraoperative blood loss.

\section{MATERIAL AND METHODS}

Outcomes of 44 patients treated for grade III degenerative coxarthrosis $(\mathrm{n}=21$, OA group) and RA coxarthrosis ( $n=23$, RA group) with primary THR in Ekaterinburg regional hospital № 1 between 2018 and 2019 were reviewed. There were 23 female
$(75 \%)$ and 11 male $(25 \%)$ patients. The majority $(67.4 \%)$ were patients of working age but many of them were unemployed due to severe pain at the time of admission. All patients underwent comprehensive clinical examinations before the operation to confirm 
the diagnosis and determine severity of the disease. The inclusion criteria were definitive diagnosis of metabolicdystrophic coxarthrosis, confirmed by clinical and radiological findings, and RA associated coxarthrosis in accordance with the 2010 ACR/EULAR (the European League Against Rheumatism) Classification Criteria for RA, patients aged 41 to 70 years, the patient's consent to participate in the study. The exclusion criteria were patients younger than 41 and older than 70 years, severe co-morbidities at the stage of exacerbation or decompensation that could affect the results of the study.

The main group included 23 RA patients (RA group), the control group consisted of 21 patients with metabolicdystrophic coxarthrosis (OA group). There were $2 \mathrm{RA}$ and 8 OA male patients $(\mathrm{p}=0.247)$. The mean age of patients was $57.2 \pm 8.4$ years (mean $\pm \mathrm{SD}$ ) in RA group and $57.3 \pm 7.2$ years in OA group (mean $\pm \mathrm{SD})(\mathrm{p}=0.762)$. Concomitant somatic pathology was encountered in 39 cases $(88.6 \%)$. Most patients suffered from hypertension (52.7\%), type II diabetes mellitus (6.5\%), gastritis (13.4\%). Overweight was observed in $73.9 \%$ of cases, grades I-II obesity detected in 18 (39.1\%) patients. At the time of recruitment, $68.75 \%$ of RA patients received basic anti-inflammatory therapy with methotrexate (43.75\%), sulfasalazine ( $25 \%$ ) and leflunomide (6.25\%) administered. Glucocorticoids prescribed for $81.25 \%$ of patients included prednisone 5 to $15 \mathrm{mg}$ per day $(62.5 \%)$, methylprednisolone 4 to $48 \mathrm{mg}$ per day (18.75\%).

An enhanced system of preoperative patient preparation to reduce surgical stress (Fast track surgery), combined with the enhanced recovery after surgery (ERAS) postoperative pathway active postoperative rehabilitation has been employed at the hospital since 2018 and allowed the most effective surgical treatment of trauma and orthopaedic patients with minimal risk of complications.

Prior to THR RA patients were admitted to the specialized rheumatology department of the Ekaterinburg regional hospital № 1 for 2 weeks to undergo comprehensive examinations and conservative treatment to improve RA and anemia. All patients were operated by one surgical team and primary total hip arthroplasty was performed using the standard DePuy cemented $(n=24)$ and cementless (20) systems and the anterolateral approach as modified by Muller modification with the patient positioned in the lateral decubitus. Patients received Fragmin 2500 IU 12 hours before the operation, Cefazolin $2 \mathrm{~g} 30$ minutes preoperatively.

Thelength of the procedure fromanesthesiaintroduced to aseptic dressings applied was $80.4 \pm 21.1$ minutes in the RA group and $83.1 \pm 23.3$ minutes in the OA group. The introduction of crystalloids was performed intraoperatively in all patients according to the standard protocol. Blood loss was measured by the volume of aspirate in the Armed 7E-A operational suction (Russia). Hemostasis cloths and wound drying were not used intraoperatively in both groups. Postoperative wounds were sutured without drains. Blood loss was also assessed by a decreased red blood cells (RBC) count and hemoglobin on the first postoperative day. No blood transfusions were performed perioperatively in the cases. There were no complications of surgical treatment in both study groups. The use of the principles of "fast track" surgery, as well as ERAS, including the selection of anesthesia methods, minimally invasive methods of surgical treatment, optimal pain control and active postoperative recovery, reduced reactions to stress and organ dysfunction, significantly reducing the time required for full recovery. The duration of inpatient treatment was $10 \pm 2$ days. The study groups were comparable in gender, age, stage of the disease, concomitant disorders, perioperative management, type of surgical intervention, surgical technique, method of implant fixation and type of implantation system used.

Cell counting was produced with the Sysmex XT-4000i automated hematology system. Blood samples were collected in test tubes with K2EDTA (dipotassium ethylenediaminetetraacetic acid) as an anticoagulant and analyzed within one hour after venepuncture to rule out platelet swelling [14]. Statistical analysis was performed using the tools of Statistica software. Non-parametric Mann-Whitney test was used to compare cell counts between the groups. The Spearman Rank correlation was used to analyze the correlation between the cell counts in the groups. For calculations, a significance level of $p<0.05$ was adopted. Compliance with ethical principles: patients signed a voluntary informed consent to publish the findings without identification.

\section{RESULTS}

Hematological parametersmeasured preoperatively and on the first day after surgery are presented in Table 1. No significant differences in the total leukocyte count, neutrophil, lymphocyte, monocyte, eosinophil counts were found preoperatively between RA and OA groups. The RA group showed decreased $\mathrm{RBC}$ counts and a significant decrease in hemoglobin levels as compared to the OA group. There were significant differences in platelet counts between the groups with significantly higher levels in the
RA group with significantly lower MPV than that in the OA group.

A day after THR most parameters changed in both groups with increase in the total leukocyte count, neutrophils, in particular, decreased lymphocyte, erythrocyte, platelet counts, hemoglobin and thrombocrit levels. There were no significant differences in RBC and white blood cell (WBC) counts after the operation between the groups. The differences in the MPV between the groups were leveled out with 
a higher level of platelets persisted in the RA group as compared to that in the OA group. Measurements of blood loss during THR procedure showed no statistically significant differences between the groups with lower level of blood loss in the RA group as compared to the OA patients: $210[200 ; 270]$ and 230 [210; 290] mL (Fig. 1a).
The drop in erythrocyte count was significantly less in the RA group as compared to that in the OA group: 0.73 $[0.52 ; 1.02]$ and $1.01[0.83 ; 1.41] \times 106 / \mu 1$, respectively $(\mathrm{p}=0.038)$ (Fig. 1b). The drop in hemoglobin level was also less in the RA group compared to the OA group: $23.0[12.0 ; 31.0]$ and $29.0[23.0 ; 36.0] \mathrm{g} / \mathrm{L}$, respectively $(\mathrm{p}=0.068)$ (Fig. 1c).

Table 1

Hematological parameters in RA and OA patients prior to THR and a day after surgery

\begin{tabular}{|l|c|c|c|c|c|c|}
\hline \multirow{2}{*}{\multicolumn{1}{c|}{ Parameter }} & \multicolumn{2}{|c|}{ Preoperatively } & \multicolumn{3}{c|}{ A day after surgery } \\
\cline { 2 - 7 } & RA & OA & $p$ & RA & OA & $p$ \\
\hline Leucocytes $\left(\times 10^{3} / \mathrm{mcL}\right)$ & $7.60[5.92 ; 9.30]$ & $6.60[5.50 ; 8.50]$ & 0.354 & $10.20[9.20 ; 11.20]$ & $8.54[7.50 ; 10.51]$ & 0.159 \\
\hline Neutrophils $\left(\times 10^{3} / \mathrm{mcL}\right)$ & $4.40[3.10 ; 6.36]$ & $3.98[3.22 ; 4.50]$ & 0.316 & $7.47[6.89 ; 8.80]$ & $6.37[5.25 ; 7.91]$ & 0.212 \\
\hline Lymphocytes $\left(\times 10^{3} / \mathrm{mcL}\right)$ & $2.07[1.69 ; 2.94]$ & $1.93[1.52 ; 2.49]$ & 0.430 & $1.35[1.13 ; 1.56]$ & $1.26[1.00 ; 1.49]$ & 0.475 \\
\hline Monocytes $\left(\times 10^{3} / \mathrm{mcL}\right)$ & $0.54[0.43 ; 0.75]$ & $0.51[0.40 ; 0.66]$ & 0.381 & $0.94[0.74 ; 1.05]$ & $1.02[0.71 ; 1.16]$ & 0.263 \\
\hline Eosinophils $\left(\times 10^{3} / \mathrm{mcL}\right)$ & $0.08[0.00 ; 0.16]$ & $0.06[0.00 ; 0.10]$ & 0.790 & $0.04[0.01 ; 0.11]$ & $0.03[0.01 ; 0.09]$ & 0.405 \\
\hline Basophils $\left(\times 10^{3} / \mathrm{mcL}\right)$ & $0.03[0.00 ; 0.05]$ & $0.01[0.00 ; 0.02]$ & 0.233 & $0.02[0.01 ; 0.04]$ & $0.01[0.01 ; 0.03]$ & 0.147 \\
\hline Erythrocytes $\left(\times 10^{6} / \mathrm{mcL}\right)$ & $4.37[4.10 ; 4.68]$ & $4.75[4.30 ; 4.98]$ & 0.086 & $3.65[3.23 ; 4.01]$ & $3.71[3.27 ; 4.03]$ & 0.839 \\
\hline Hemoglobin $(\mathrm{g} / \mathrm{L})$ & $133.0[119.0 ; 136.0]$ & $140.0[124.0 ; 146.0]$ & 0.031 & $107.0[103.0 ; 113.0]$ & $107.0[102.0 ; 116.0]$ & 0.228 \\
\hline Platelets $\left(\times 10^{3} / \mathrm{mcL}\right)$ & $257.0[233.0 ; 306.0]$ & $219.0[178.0 ; 262.0]$ & 0.026 & $213.0[174.0 ; 267.0]$ & $170.0[146.0 ; 225.0]$ & 0.025 \\
\hline MPV $(\mathrm{fL})$ & $8.7[8.3 ; 10.0]$ & $9.9[9.1 ; 10.8]$ & 0.043 & $9.8[8.6 ; 10.6]$ & $10.1[9.5 ; 10.5]$ & 0.17 \\
\hline
\end{tabular}

Note: RA - rheumatoid arthritis; OA - osteoarthritis; MPV, mean platelet volume; $\mathrm{p}$ - statistical significance of differences between RA and OA groups. The results are presented as the median [interquartile interval].
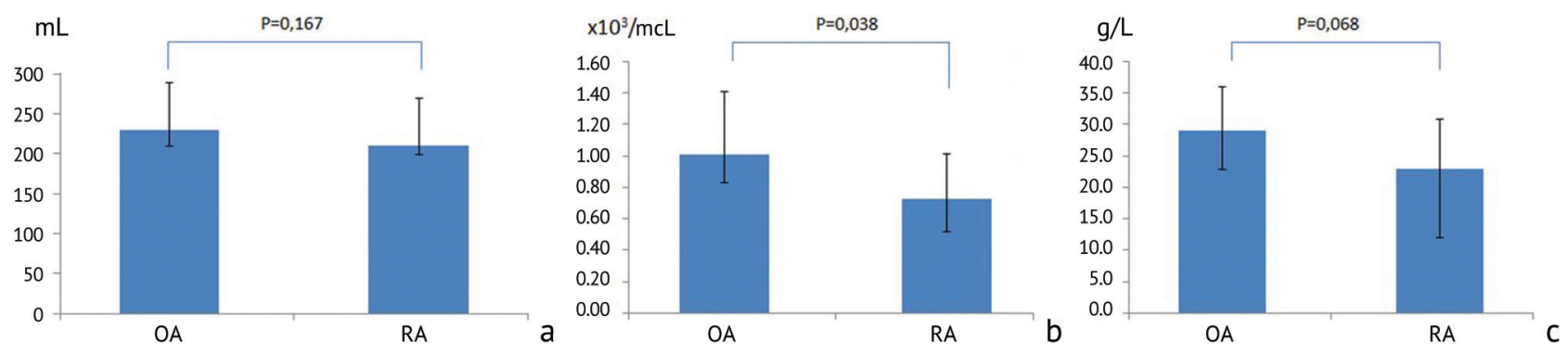

Fig. 1 Blood loss (a), decreased erythrocyte (b) and hemoglobin (c) levels in patients with osteoarthritis (OA) and rheumatoid arthritis (RA) during THR. The results are presented as the median [interquartile interval]

\section{DISCUSSION}

Anemia is reported in $33-60 \%$ of RA patients $[15,16]$ and correlated with the intensity of the condition $[17,18]$. There is a relationship between anemia and disability in RA patients revealed [19]. Anemia at chronic conditions and iron deficiency anemia are most common [20-22]. The mechanisms of anemia are not completely clear but inflammatory cytokines IL 6 and TNF- $\alpha$ are known to affect the regulation of iron metabolism by stimulating the production of the hepcidin hormone that causes degradation of the transmembrane protein ferroportin [20]. In addition to that, erythropoiesis, proliferation of erythroid precursors, erythropoietin production and erythrocyte lifespan appear to be impaired [15, 23]. Our series showed that preoperative erythrocyte and hemoglobin levels are lower in RA patients than those in OA patients and are associated with the inflammatory process in RA and are consistent with the data of other authors $[24,25]$. The hemoglobin level was below 120 $\mathrm{g} / \mathrm{L}$ in $30.4 \%$ of RA patients of the series and not below $110 \mathrm{~g} / \mathrm{L}$. None of the patients had hemoglobin level below $80 \mathrm{~g} / \mathrm{L}$ after surgery. Although gravimetric and visual methods are used to evaluate blood loss they cannot be considered accurate [26]. In addition to that, a significant portion of the blood flowing from injured vessels can be located in the soft tissues during hip replacement surgery. In recent years, drainage systems have not been used for replacement of major joints to reduce the risk of postoperative periprosthetic joint infection [27-29]. Drains were not used in our series and postoperative blood loss could not be measured with drains. We could measure blood loss through reduced level of erythrocytes and hemoglobin in addition to measuring the volume of aspiration contents in "Armed 7E-A" (Russia). Measurement of hemoglobin concentration for assessment of intraoperative blood loss is also reported by other authors [30, 31]. Intraoperative blood loss in 
RA patients was no greater than that in OA patients. The tendency to less voluminous blood loss in RA patients can be explained by active formation of clots treaing vascular injuries during surgical procedure. The assumption is based on a higher level of platelets that are primarily involved in hemostasis. There is a close correlation between the functional activity of platelets, markers of inflammation and the course of RA [32].

The researchers studying the morphofunctional characteristics of platelets in RA patients report significant changes in cell counts, mean platelet volume (MPV), plateletcrit (PCT), platelet distribution width (PDW) in RA [33-36]. However, there is no consensus on the nature of these changes. MPV in RA patients was shown to have a positive correlation with markers of inflammation and severity of the disease, and the parameter decreased after treatment [34]. In contrast, D.A. Kim and T.Y. Kim compared hematological parameters ofOA and RA patients and found significantly higher platelet counts in RA patients and significantly lower MPV and PDW [35]. B. Kisacik et al. reported significantly lower MPV in RA patients than that in OA patients that increased after treatment remaining significantly lower than that in OA patients [33]. Iş1k et al. reported positive correlation of PCT and C-reactive protein, and a negative correlation of MPV and PDW and the marker of inflammation in RA patients [36]. We found that RA patients had a positive correlation between leukocyte count and PCT (Spearman correlation coefficient $\mathrm{rs}=0.48 ; \mathrm{p}<0.05)$ and a negative correlation between leukocyte count and MPV ( $r s=-0.43 ; p<0.05)$ that could be explained by associated platelet parameters and the level of inflammation.

We found that RA patients had significantly lower MPV than that in OA patients. MPV is a very important morphofunctional parameter. Platelets of greater volume have a higher procoagulation and proinflammatory potential and contain a large number of relevant components in their granules that are released during activation [37]. Activated platelets produce microparticles that are involved in the pathogenesis of RA and play an important role in antigen presentation, inflammation, angiogenesis, cells' signaling and degradation of the extracellular matrix of articular cartilage [38, 32]. Microparticles secreted by platelets also carry activators of the coagulation process [39]. Decreased platelet volume in RA patients observed in our series could indicate to greater microparticles produced by platelets that could form clots more quickly to prevent blood loss.
D.A. Kim and T.Y. Kim compared the leukocyte counts of OA and RA patients and reported significantly higher leukocyte count, neutrophils, in particular, in RA patients [35]. Neutrophils play an important role in the initial stages of rheumatoid arthritis: they migrate into the joint cavity at an early stage, become activated and are involved in the inflammatory process. Extracellular neutrophil traps (NETS) are involved in the production of autoantibodies against citrullinated proteins that initiate an immune response in rheumatoid arthritis. Proinflammatory cytokines stimulate neutrophil migration, apoptosis and NETs formation [40, 41]. RA patients may also have neutropenia that is usually associated with the presence of Felty syndrome or T-cell leukemia from large granular leukocytes [42, 43].

Neutrophil lysis is known to play an important role in the pathogenesis of RA, since the death of neutrophil cells leads to the stimulation of citrullination, posttranslational modification of protein catalyzed by peptidyl arginine deiminases converting arginine to citrulline [44, 45]. RA and OA patients showed no significant differences in the total leukocyte and neutrophil counts. Eosinophils are multifunctional leukocytes with a wide range of immune modulatory factors [46]. They were shown to have an anti-inflammatory effect in RA patients being able to induce the formation of an "anti-inflammatory" M2 phenotype in macrophages by inhibiting the IkB/ P38 MAP kinase signaling pathway [47]. We found no preoperative differences in the level of leukocytes of this type in RA and OA patients. In general, WBC count and the ratio in RA patients was close to that in OA patients after preoperative preparation at the rheumatology department of the Ekaterinburg regional hospital № 1. It can be assumed that the preoperative level of the inflammatory process was characterized by a similar level of severity. Hemoglobin was not less than $100 \mathrm{~g} / \mathrm{L}$ in RA patients as a result of preoperative corrective treatment and meant mild anemia. Thus, the absence of perioperative hemotransfusions, clinically pronounced thromboembolic and other postoperative complications in RA patients could be considered a consequence of adequate preoperative preparation. Our findings are consistent with those of the series reporting the incidence of complications in RA patients being not higher than that in OA patients undergoing THR at a specialized center $[9,11,48]$. The review of THRs performed for more than 120 thousand of OA patients and for more than 6 thousand RA patients showed that RA patients had equipollent perioperative risks [49].

\section{CONCLUSION}

Hip replacement surgery is one of the most effective and complicated orthopaedic procedures that helps to restore painless movements in the affected joint within a short rehabilitation period. Patients with systemic diseases of the connective tissue, rheumatoid arthritis, in particular, with porous changes in bone tissue due to 
prolonged immunosuppressive therapy are a specific case. In addition to the technical problems of prosthesis implantation into the involved pelvic and femoral bones, RA patients may have an increased risk of general complications due to anemia and low hemoglobin levels.

We suggested that hematological parameters of RA patients who had undergone specific preoperative preparation were not shown to be associated with greater blood loss during hip replacement surgery. The leukocyte count leveled up in the preoperative and early postoperative periods can be indicative of the absence of a significant effect of RA on the postoperative inflammation. Severe general and local complications of total hip arthroplasty can be prevented through thorough preoperative examination, specialized medical preparation aimed at reducing inflammation and anemia, technological atraumatic surgical procedure and early postoperative rehabilitation.

\section{REFERENCES}

1. Osnes-Ringen H., Kvien T.K., Henriksen J.E., Mowinckel P., Dagfinrud H. Orthopaedic surgery in 255 patients with inflammatory arthropathies: longitudinal effects on pain, physical function and health-related quality of life. Ann. Rheum. Dis., 2009, vol. 68, no. 10 , pp. 1596-1601.

2. Volokitina E.A., Ershov A.S., Khabib M. Endoprotezirovanie tazobedrennogo sustava pri protruzionnoi deformatsii vertluzhnoi vpadiny na fone revmatoidnogo artrita, oslozhnennogo podvertelnym perelomom bedrennoi kosti. Sluchai iz praktiki [Hip arthroplasty for protrusion acetabular deformity through rheumatoid arthritis complicated by subtrochanteric femoral fracture. Case report]. Uralskii Meditsinskii Zhurnal, 2018, no. 4, pp. 117-120. (in Russian)

3. Antropova I., Yushkov B., Shlykov I., Volokitina E. Influence of preoperative platelet activity on coagulation and blood loss in large orthopedic surgery. Research and Practice in Thrombosis and Haemostasis. 2018. Vol. 2, No S1. Special Issue: abstracts of the $64^{\text {th }}$ Annual Meeting of the Scientific Standardization Committee of the International Society on Thrombosis and Haemostasis (July 18-21, 2018). P. 9-10.

4. Salt E., Wiggins A.T., Rayens M.K., Brown K., Eckmann K., Johannemann A., Wright R.D., Crofford L.J. Risk Factors for Transfusions Following Total Joint Arthroplasty in Patients With Rheumatoid Arthritis. J. Clin. Rheumatol., 2018, vol. 24, no. 8, pp. 422-426. DOI: 10.1097/RHU.0000000000000755.

5. Imagama T., Tokushige A., Seki K., Seki T., Ogasa H., Taguchi T.. Risk Factors Associated With Short-term Clinical Results After Total Hip Arthroplasty for Patients With Rheumatoid Arthritis. Orthopedics, 2018, vol. 41, no. 6, pp. e772-e776. DOI: 10.3928/01477447-20180828-06.

6. Antropova I.P., Volokitina E.A., Arkhipova A., Gilev M.V., Kutepov S.M. Mean Platelet Volume and Blood Loss in Total Hip Replacement Surgery. Research and Practice in Thrombosis and Haemostasis. 2019. Vol. 3, Special Issue: abstracts of the XXVII Congress of the International Society on Thrombosis and Haemostasis (July 6-10, 2019). P. 213-214. Available at: https:// onlinelibrary.wiley.com/toc/24750379/2019/3/S1.

7. Soohoo N.F., Farng E., Lieberman J.R., Chambers L., Zingmond D.S. Factors that predict short-term complication rates after total hip arthroplasty. Clin. Orthop. Relat. Res., 2010, vol. 468, no. 9, pp. 2363-2371. DOI: 10.1007/s11999-010-1354-0.

8. Bongartz T., Halligan C.S., Osmon D.R., Reinalda M.S., Bamlet W.R., Crowson C.S., Hanssen A.D., Matteson E.L. Incidence and risk factors of prosthetic joint infection after total hip or knee replacement in patients with rheumatoid arthritis. Arthritis Rheum., 2008, vol. 59, no. 12, pp. 1713-1720. DOI: 10.1002/art.24060.

9. Lee D.K., Kim H.J., Lee D.H. Incidence of Deep Vein Thrombosis and Venous Thromboembolism following TKA in Rheumatoid Arthritis versus Osteoarthritis: A Meta-Analysis. PLoS One, 2016, vol. 11, no. 12, pp. e0166844. DOI: 10.1371/journal.pone.0166844.

10.Goodman S.M., Johnson B., Zhang M., Huang W.T., Zhu R., Figgie M., Alexiades M., Mandl L.A. Patients with Rheumatoid Arthritis have Similar Excellent Outcomes after Total Knee Replacement Compared with Patients with Osteoarthritis. J. Rheumatol., 2016, vol. 43, no. 1, pp. 46-53. DOI: 10.3899/jrheum.150525.

11.LoVerde Z.J., Mandl L.A., Johnson B.K., Figgie M.P., Boettner F., Lee Y.Y., Goodman S.M. Rheumatoid Arthritis Does Not Increase Risk of Short-term Adverse Events After Total Knee Arthroplasty: A Retrospective Case-control Study. J. Rheumatol., 2015, vol. 42, no. 7, pp. 1123-1130. DOI: 10.3899/jrheum.141251.

12.Bowman S.J. Hematological manifestations of rheumatoid arthritis. Scand. J. Rheumatol., 2002, vol. 31, no. 5, pp. 251-259. DOI: 10.1080/030097402760375124.

13.Ahmadi H., Jamshidi A.R., Mahmoudi M., Gharibdoost F., Vojdanian M., Fattahi M.J., Rastkari N., Aghazadeh Z., Mirshafiey A. Hematological Improvement of Patients with Active Rheumatoid Arthritis by $\beta$-D-Mannuronic Acid (M2000) as a Novel NSAID with Immunosuppressive Property. Iran J. Allergy Asthma Immunol., 2017, vol. 16, no. 5, pp. 433-442.

14.Dastjerdi M.S., Emami T., Najafian A., Amini M. Mean platelet volume measurement, EDTA or citrate? Hematology, 2006, vol. 11, no. 5, pp. 317-319. DOI: 10.1080/10245330600954163.

15.Galushko E.A. Klinicheskoe znachenie opredeleniia gep-sidina pri anemii u bolnykh revmatoidnym artritom [The clinical significance of hepcidin detection in the patients with anemia and rheumatoid arthritis]. Klin. Med. (Mosk), 2014, vol. 92, no. 6, pp. 21-27. (in Russian)

16.Wilson A., Yu H.T., Goodnough L.T., Nissenson A.R. Prevalence and outcomes of anemia in rheumatoid arthritis: a systematic review of the literature. Am. J. Med., 2004, vol. 116, no. Suppl. 7A, pp. 50S-57S. DOI: 10.1016/j.amjmed.2003.12.012.

17.Jia W., Wang S., Han K., Liu M., Yang S., Cao W., He Y. Association of Anemia with Activities of Daily Living in Chinese Female Centenarian. J. Nutr. Health Aging, 2020, vol. 24, no. 3, pp. 346-351. DOI: 10.1007/s12603-020-1326-3.

18.Goyal L., Shah P.J., Yadav R.N., Saigal R., Agarwal A., Banerjee S. Anaemia in Newly Diagnosed Patients of Rheumatoid Arthritis and its Correlation with Disease Activity. J. Assoc. Physicians India, 2018, vol. 66, no. 5, pp. 26-29.

19.Han C., Rahman M.U., Doyle M.K., Bathon J.M., Smolen J., Kavanaugh A., Westhovens R., St Clair E.W., Baker D., Bala M. Association of anemia and physical disability among patients with rheumatoid arthritis. J. Rheumatol., 2007, vol. 34, no. 11, pp. 2177-2182. 
20.Grinshtein Y.I., Shabalin V.V., Kusaev V.V. Anemicheskii sindrom pri revmatoidnom artrite: podkhody k diagnostike i vozmozhnosti terapii [Anemic syndrome in rheumatoid arthritis: Diagnostic approaches and treatment opportunities]. Ter. Arkh., 2016, vol. 88, no. 5, pp. 107-112. DOI: 10.17116/terarkh2016885107-112. (in Russian)

21.Agrawal S., Misra R., Aggarwal A. Anemia in rheumatoid arthritis: high prevalence of iron-deficiency anemia in Indian patients. Rheumatol. Int., 2006, vol. 26, no. 12, pp. 1091-1095. DOI: 10.1007/s00296-006-0133-4.

22.Elsheemy M.S., Hasanin A.H., Mansour A., Mehrez S.I., Abdel-Bary M. Etanercept improved anemia and decreased hepcidin gene expression in a rat model of rheumatoid arthritis. Biomed. Pharmacother., 2019, vol. 112, pp. 108740. DOI: 10.1016/j. biopha.2019.108740.

23.Papadaki H.A., Kritikos H.D., Valatas V., Boumpas D.T., Eliopoulos G.D. Anemia of chronic disease in rheumatoid arthritis is associated with increased apoptosis of bone marrow erythroid cells: improvement following anti-tumor necrosis factor-alpha antibody therapy. Blood, 2002, vol. 100, no. 2, pp. 474-482. DOI: 10.1182/blood-2002-01-0136.

24.Morse K.W., Heinz N.K., Abolade J.M., Wright-Chisem J.I., Russell L.A., Zhang M., Mirza S.Z., Orange D.E., Figgie M.P., Sculco P.K., Goodman S.M. Tranexamic Acid Does Not Reduce the Risk of Transfusion in Rheumatoid Arthritis Patients Undergoing Total Joint Arthroplasty. J. Arthroplasty, 2020, vol. 35, no. 9, pp. 2367-2374. DOI: 10.1016/j.arth.2020.04.029.

25.Rao S.S., Chaudhry Y.P., Hasan S.A., Puvanesarajah V., Amin R.M., Oni J.K., Sterling R.S., Khanuja H.S. Factors Associated With Perioperative Transfusion in Lower Extremity Revision Arthroplasty Under a Restrictive Blood Management Protocol. J. Am. Acad. Orthop. Surg., 2021, vol. 29, no. 8, pp. e404-e409. DOI: 10.5435/JAAOS-D-20-00185.

26.Konig G., Waters J.H., Javidroozi M., Philip B., Ting V., Abbi G., Hsieh E., Tully G., Adams G. Real-time evaluation of an image analysis system for monitoring surgical hemoglobin loss. J. Clin. Monit. Comput., 2018, vol. 32, no. 2, pp. 303-331. DOI: 10.1007/ s10877-017-0016-0.

27.Lychagin A.V., Gritsiuk A.A., Gasymov A.Sh. Voprosy drenirovaniia rany pri pevichnom endoprotezirovanii tazobedrennogo sustava (literaturnyi obzor) [Wound drainage problems for primary hip arthroplasty (Review of the literature)]. Kafedra Travmatologii $i$ Ortopedii, 2018, no. 1(31), pp. 28-33. (in Russian)

28.Grechaniuk N.D., Zverkov A.V., Ovsiankin A.V., Zhiburt E.B. Vliianie drenirovaniia posleoperatsionnoi rany na chastotu transfuzii eritrotsitov posle pervichnogo endoprotezirovaniia tazobedrennogo sustava [Influence of postoperative wound draining on the frequency of erythrocyte transfusions after primary arthroplasty of the hip]. Vestnik Travmatologii i Ortopedii im. N.N. Priorova, 2006, no. 4, pp. 12-16. (in Russian)

29. Nakopiia V.B., Kornilov N.N., Bozhkova S.A., Kazemirskii A.V., Goncharov M.Iu. Skrytaia krovopoteria posle totalnogo endoprotezirovaniia kolennogo sustava na fone kompleksnoi antikoaguliantnoi tromboprofilaktiki [Latent blood loss after total knee arthroplasty against the background of complex anticoagulant thromboprophylaxis]. Sovremennye Problemy Nauki i Obrazovaniia, 2017, no. 6, pp. 97. (in Russian) Available at: http://www.science-education.ru/ru/article/view?id $=27272$ (accessed 10.02.2021).

30.Huang P.H., Shih B.F., Tsai Y.F., Chung P.C., Liu F.C., Yu H.P., Lee W.C., Chang C.J., Lin C.C. Accuracy and Trending of Continuous Noninvasive Hemoglobin Monitoring in Patients Undergoing Liver Transplantation. Transplant. Proc., 2016, vol. 48, no. 4, pp. 1067-1070. DOI:10.1016/j.transproceed.2015.12.121.

31.Carson J.L., Guyatt G., Heddle N.M., Grossman B.J., Cohn C.S., Fung M.K., Gernsheimer T., Holcomb J.B., Kaplan L.J., Katz L.M., Peterson N., Ramsey G., Rao S.V., Roback J.D., Shander A., Tobian A.A. Clinical Practice Guidelines From the AABB: Red Blood Cell Transfusion Thresholds and Storage. JAMA, 2016, vol. 316, no. 19, pp. 2025-2035. DOI: 10.1001/jama.2016.9185.

32.Olumuyiwa-Akeredolu O.O., Page M.J., Soma P., Pretorius E. Platelets: Emerging Facilitators of Cellular Crosstalk in Rheumatoid Arthritis. Nat. Rev. Rheumatol., 2019, vol. 15, no. 4, pp. 237-248. DOI: 10.1038/s41584-019-0187-9.

33.Kisacik B., Tufan A., Kalyoncu U., Karadag O., Akdogan A., Ozturk M.A., Kiraz S., Ertenli I., Calguneri M. Mean platelet volume (MPV) as an inflammatory marker in ankylosing spondylitis and rheumatoid arthritis. Joint Bone Spine, 2008, vol. 75, no. 3, pp. 291-294. DOI: 10.1016/j.jbspin.2007.06.016.

34. Yazici S., Yazici M., Erer B., Erer B., Calik Y., Ozhan H., Ataoglu S. The platelet indices in patients with rheumatoid arthritis: mean platelet volume reflects disease activity. Platelets, 2010, vol. 21, no. 2, pp. 122-125. DOI: 10.3109/09537100903474373.

35.Kim D.A., Kim T.Y. Controversies Over the Interpretation of Changes of Mean Platelet Volume in Rheumatoid Arthritis. Platelets, 2011, vol. 22, no. 1, pp. 79-80. DOI: 10.3109/09537101003663758.

36.Işık M., Şahin H., Hüseyin E. New Platelet Indices as Inflammatory Parameters for Patients With Rheumatoid Arthritis. Eur. J. Rheumatol., 2014, vol. 1, no. 4, pp. 144-146. DOI: 10.5152/eurjrheumatol.2014.140023.

37.Korniluk A., Koper-Lenkiewicz O.M., Kamińska J., Kemona H., Dymicka-Piekarska V. Mean Platelet Volume (MPV): New Perspectives for an Old Marker in the Course and Prognosis of Inflammatory Conditions. Mediators Inflamm., 2019, vol. 2019, pp. 9213074. DOI: 10.1155/2019/9213074.

38.Harifi G., Sibilia J. Pathogenic role of platelets in rheumatoid arthritis and systemic autoimmune diseases. Perspectives and therapeutic aspects. Saudi Med J., 2016, vol. 37, no. 4, pp. 354-360. DOI: 10.15537/smj.2016.4.14768.

39.Fu H., Hu D., Zhang L., Tang P. Role of extracellular vesicles in rheumatoid arthritis. Mol. Immunol., 2018, vol. 93, pp. 125-132. DOI:10.1016/j.molimm.2017.11.016.

40.Cecchi I., Arias de la Rosa I., Menegatti E., Roccatello D., Collantes-Estevez E., Lopez-Pedrera C., Barbarroja N. Neutrophils: Novel key players in Rheumatoid Arthritis. Current and future therapeutic targets. Autoimmun. Rev., 2018, vol. 17, no. 11, pp. 11381149. DOI: 10.1016/j.autrev.2018.06.006.

41.Chen W., Wang Q., Ke Y., Lin J. Neutrophil Function in an Inflammatory Milieu of Rheumatoid Arthritis. J. Immunol. Res., 2018, vol. 2018, pp. 8549329. DOI: 10.1155/2018/8549329.

42.Sigidin Ya.A., Lukina G.V., Posdnyakova E.S. Sindrom Felti i T-kletochnyi leikoz iz bolshikh granuliarnykh leikotsitov zakonomernoe sochetanie [Felty syndrome and large granular leukocyte T-cell leukemia - a natural combination]. Rheumatology Science and Practice, 2007, vol. 45, no. 3, pp. 105-108. (In Russian) Available at: https://doi.org/10.14412/1995-4484-2007-696.

43.Gazitt T., Loughran T.P. Jr. Chronic neutropenia in LGL leukemia and rheumatoid arthritis. Hematology Am. Soc. Hematol. Educ. Program, 2017, vol. 2017, no. 1, pp. 181-186. DOI: 10.1182/asheducation-2017.1.181. 
44.Romero V., Fert-Bober J., Nigrovic P.A., Darrah E., Haque U.J., Lee D.M., van Eyk J., Rosen A., Andrade F. Immune-mediated pore-forming pathways induce cellular hypercitrullination and generate citrullinated autoantigens in rheumatoid arthritis. Sci. Transl. Med., 2013, vol. 5, no. 209, pp. 209ra150. DOI: 10.1126/scitranslmed.3006869.

45.Lood C., Blanco L.P., Purmalek M.M., Carmona-Rivera C., De Ravin S.S., Smith C.K., Malech H.L., Ledbetter J.A., Elkon K.B., Kaplan M.J. Neutrophil extracellular traps enriched in oxidized mitochondrial DNA are interferogenic and contribute to lupus-like disease. Nat. Med., 2016, vol. 22, no. 2, pp. 146-153. DOI: 10.1038/nm.4027.

46.Kolobovnikova Iu.V., Urazova O.I., Novitskii V.V., Litvinova L.S., Chumakova S.P. Eozinofil: sovremennyi vzgliad na kinetiku, strukturu i funktsiiu [Eosinophil: a modern view of kinetics, structure and function]. Gematologiia i Transfuziologiia, 2012, vol. 57, no. 1, pp. 30-36. (in Russian)

47.Liu L., Zhang Y., Zheng X., Jin L., Xiang N., Zhang M., Chen Z. Eosinophils attenuate arthritis by inducing M2 macrophage polarization via inhibiting the IкB/P38 MAPK signaling pathway. Biochem. Biophys. Res. Commun., 2019, vol. 508, no. 3, pp. 894901. DOI: 10.1016/j.bbrc.2018.12.010.

48.Ravi B., Croxford R., Austin P.C., Hollands S., Paterson J.M., Bogoch E., Kreder H., Hawker G.A. Increased surgeon experience with rheumatoid arthritis reduces the risk of complications following total joint arthroplasty. Arthritis Rheumatol., 2014, vol. 66, no. 3, pp. 488-496. DOI: 10.1002/art.38205.

49.Pan X., Wang J., Shi Z., Cheng H., Lin Z., Wu X., Shi Z. Rheumatoid Arthritis Versus Osteoarthritis in Patients Receiving Revision Total Knee Arthroplasty in the United States: Increased Perioperative Risks? A National Database-Based Propensity Score-Matching Study. J. Am. Acad. Orthop. Surg., 2021. DOI: 10.5435/JAAOS-D-20-00979.

The article was submitted 17.11.2020; approved after reviewing 03.03.2021; accepted for publication 23.08.2021.

\section{Information about the authors:}

1. Anton S. Ershov - M.D., drpilulkin@mail.ru;

2. Irina P. Antropova - Doctor of Biological Sciences, aip.hemolab@mail.ru;

3. Elena A. Volokitina - Doctor of Medical Sciences, volokitina_elena@rambler.ru;

4. Ludmila P. Evstigneeva - Doctor of Medical Sciences, levstigneyeva@mail.ru.

Conflict of interests The authors declare that there is no conflicts of interests.

Funding The research was carried out as part of the state research project at the Institute of Traumatology and Orthopaedics of the Central Research Institute of the UGMU of the Ministry of Health of the Russian Federation; with the financial support of the Ministry of Education and Science of the Russian Federation.

Compliance with the principles of ethics The design of the study was approved by the local Ethics Committee of the State Autonomous Healthcare Institution of the Sverdlovsk Region "Sverdlovsk Regional Clinical Hospital No. 1", 620102, Yekaterinburg, Volgogradskaya str., 185. All participants signed an informed consent to participate in the study. 